\title{
The Workfare Illusion: Re-examining the Concept and the British Case
}

\author{
Jörg Michael Dostal
}

\begin{abstract}
This article contends that workfare programmes pursued by various OECD countries since the mid-Iggos do not amount to a fundamental change in policy. The limited potential of workfare is due to the fact that it fails to transcend the constraints of earlier forms of 'active' responses to unemployment. Furthermore, it suffers from specific policy-making disadvantages not shared by these responses. The article opens with a survey of relevant academic debates on the subject. It then places workfare in a broader context by identifying its functional reach, as compared to other active policy responses to unemployment such as active labour market policy (ALMP). The third section analyses workfare policies in the United Kingdom, as developed since 1997, by reexamining the British New Deal employment programme. That review demonstrates that workfare policies either depend on their 'fit' with the existing policy-making heritage, or that they remain merely symbolic. The article concludes by suggesting that the potential of workfare to effect change in responses to unemployment continues to be of limited significance. In other words, capitalist employment and welfare systems continue to be characterized by incremental adaptation rather than by fundamental regime change as suggested by the critics of workfare.
\end{abstract}

\section{Keywords}

Active labour market policy; New Deal; Unemployment; United Kingdom; Welfare reform; Workfare

\section{Introduction}

The notion that OECD policy-makers are able to use workfare policies effectively on a large scale to replace traditional 'active' responses to unemployment, such as active labour market policies (ALMPs), is open to challenge. Here, it will be argued that the new discourse on workfare, emerging in the I99os, conceals the underlying path-dependent continuity of national policymaking in work/welfare policies, as well as the inherently cyclical pattern of ALMPs. This is not to deny that workfare policies have become relatively

Address for correspondence: förg Michael Dostal, School of Social Sciences, Marie Fahoda Building, Brunel University, Uxbridge, UBo _PH. Email: Michael.Dostal@brunel.ac.uk 
more significant in most OECD countries. However, such policies remain part of a cyclical pattern of policy-making in managing the condition of unemployment and, thus, are severely limited in scope. Workfare as part of OECD countries' welfare reform amounts to a 'groundhog day' policy: ${ }^{1}$ any announcement of new policies fails to transcend the limitations of already existing policies. Conversely, existing policies are doomed to reappear at each stage of policy reform.

Academic debate on workfare has revolved around the consequences of the abolition of the largest federal welfare benefit in the United States, the Aid for Families with Dependent Children (AFDG), that occurred in I996. The AFDC benefit had acted as a welfare payment for single mothers with dependent children. Its replacement with the new, more restrictive benefit, Temporary Assistance for Needy Families (TANF), during the second Clinton presidency triggered an OECD-wide debate on 'welfare reform', as well as other policies concerning the interaction between the out of work population, the state and the labour market. This debate tended to gloss over the differences between the unique US welfare and employment system and other OECD countries (Peters 2005). Since the mid-I99os, the language and discourse of welfare reform has proliferated along parallel lines in many different institutional settings. Terms such as 'workfare', 'welfare to work' and 'activation' started to enter national debates on labour market issues in OECD countries and the European Union (Barbier and Ludwig-Mayerhofer 2004; Dostal 2004).

In a first wave of scholarship on the broader significance of workfare policies, analysts often suggested that 'policy learning' between the USA and other OECD countries was taking place. Policy-makers in the United Kingdom were seen to be learning from the US experience and, indeed, 'policy transfer' from the latter country to the former was claimed to have occurred (Dolowitz et al. 2000). One commentator went so far as to contend that workfare was part and parcel of an underlying structural transformation of advanced capitalist countries from a 'Keynesian welfare national state' towards a 'Schumpeterian postnational workfare regime' (Jessop 2002: IOo). More recently, a second wave of analyses emerged. This questioned the earlier emphasis on cross-national learning, policy transfer and structural transformation. The second wave authors instead chose to stress the theme of national trajectories in policy-making and of cultural and institutional differences between countries (Mohr 2004; Casey and Gold 2005).

The argument presented here belongs to the second wave of scholarship, but it differs in important respects. Its point of departure is Hall's seminal analytical distinction (1993: 278-80) between policy paradigms, policy instruments and instrument settings. Hall holds that a change in policy paradigms, namely the shift from an old to a new paradigm, is the most significant indicator of policy change over time. Such a paradigm shift subsequently triggers changes in the selection of policy instrument and also influences particular instrument settings within each policy instrument. However, this raises the question of what happens if a new paradigm fails to bridge the gap between changes in the discursive framing of problems and the subsequent shift from old to new policy instruments. In other words, it asks what actually 
happens when modifications in paradigms cannot be backed up by fundamentally new policy approaches. The contention here is that workfare cannot fulfil the expectations of its advocates. On the other hand, despite the suggestion of some of its critics, the contention is also that workfare does not constitute an element of a new form of capitalism with its own employment and welfare systems.

Thus, examining workfare demonstrates that it is not a fundamentally new policy but, nevertheless, that it differs from traditional ALMP and that, at times, it can add to or replace earlier policies. It also demonstrates that workfare policies, once pursued, encounter limits that derive from the structure of the labour market. These structural limits are beyond policy-makers' ability to control, and they lay open to question the significance of the new policy at the implementation level. Whatever policy-makers' intentions happen to be, workfare is bound to disappoint them and to amount to a 'workfare illusion', as will be demonstrated below.

Furthermore, analysis of workfare as a policy instrument is also bound to be linked to broader policy-making paradigms such as recent notions of 'activation' and of the 'activating state' (Handler 2003). These policy paradigms sometimes grant workfare a high priority at the implementation level. However, they must also accommodate a variety of underlying normative political orientations. Even if notions of 'activation' become accepted as new paradigms, their interpretation remains contested. Such notions can act to support traditional ALMP as much as workfare. One author, therefore, has argued that the concept of workfare is too normative and too narrow to deserve separate analytical attention and that analysis should instead focus on the level of broader paradigms, and notably on activation (Barbier 2005: 8-9). However, it will be demonstrated that analysis at the level of policy instruments better helps to capture recent policy-making - namely 'spillover' of workfare policies from the Anglo-American to the continental European countries. Nevertheless, it will also show that this does not signify the rise of a 'workfare state'. Rather, incremental changes in the implementation of already existing national active policies are likely to occur.

\section{The Debate on Workfare}

After a summary of past and current academic debates on workfare, the broader policy-making environment of these policies will be analysed. Later, it will be shown that workfare will and must fail to deliver fundamental policy change at the implementation level. This thesis will be developed through a study of the alleged case of workfare in the UK - the New Deal employment programme for the young and long-term unemployed (and other benefit recipients) that has operated since I998. Following this, the evidence that both critics and supporters of workfare policies have overplayed their relative policy-making significance will be summarized.

The term 'workfare' comes from the USA and first entered public discourse during the Nixon presidency in the late ig6os. In the i97os, workfare was frequently used in American debates on welfare issues to describe employment programmes such as the failed plan of Michael Dukakis, Governor of 
Massachusetts, to advance a Work Experience Programme (WEP) for AFDC recipients in 1977. Another example was the Reagan administration's Community Work Experience Programme (CWEP), which passed Congress in I982, targeting welfare recipients with obligatory work programmes (Lipman 1977; Gottschalk 1998: 92). From the early 1980s, the term became used in the UK. Observers suggested, for example, that changes in rules governing public employment schemes for young people in Britain turned such programmes into 'workfare in all but name' (Lee et al. 1990: 4). Crucially, most analysts were agreed that workfare policies did not amount to a fundamental innovation in the management of work/welfare policies. Rather, observers suggested that such policies preserved and resuscitated the heritage of 'work tests' in earlier systems of poor relief such as the Victorian workhouse and of public work programmes during the world economic recession of the ig3os (Wilkinson 200I).

However, this long-standing workfare debate did not result in any agreed definition of the concept. While early commentators suggested that workfare 'was a concept in search of a programme' (Frank, quoted in Lipman I977: I43), latter-day observers could not agree what the concept entailed. This remains the case today, although programmes have certainly increasingly been implemented since the I970s. Most analysts hold that workfare relates to a concept in which 'benefits are given in return for work', thereby suggesting policies in which 'those who refuse to participate in training or employment lose state benefits' (Digby i989: 6, i I3). This basic definition of workfare states that 'mandatory work in exchange for benefits' makes welfare clients 'work off' their payments (Rose 200I). Other observers put forward a more discriminating notion, and hold that workfare policies concern only those welfare clients who find themselves in social assistance programmes of last resort. They also define three core components of workfare policies, namely (I) their compulsory character; (2) their primary focus on work; and (3) direct targeting of clients in the lowest tier of state assistance (Lødemel and Trickey 200I). Building on this definition, one author has suggested that workfare offers clients employment conditions that are inferior to comparative work in the mainstream labour market (Kildal 2000: 3).

This short, but representative, sample of opinions on workfare demonstrates conceptual ambiguity on a number of counts. First, there is no agreement about what defines the instrument settings of workfare. Therefore, one might inquire into whether one should focus on these instrument settings, or on principles that inform their application. Equally, one might ask at what point 'active' policy responses to unemployment amount to workfare and whether active programmes necessarily become workfare once they are made obligatory for clients (White 2004).

Second, it is actually unclear how the element of 'work' in workfare schemes is defined as a policy instrument. Some observers suggest that workfare includes other activities, such as training on the clients' part alongside work, that feature in other active policy responses to unemployment, particularly traditional ALMPs. One author holds, for example, that only a strict 'workfirst' feature in programme implementation defines workfare concepts proper and separates them from earlier education and training policies for the 
unemployed (Mead 200I: 529). Yet even if one accepts this concept of work-first, one would still have to scrutinize the character of 'work' that is actually performed in workfare programmes. In fact, this work falls into a variety of sub-activities, such as work for pay below the 'going rate', 'additional' work in the public sector, and various other 'activities' that could still be interpreted as 'training' as much as 'work'.

Third, the framing of workfare activities - that is, the selection of policy paradigms that inform and legitimize policy choice - is crucial for the purpose of evaluation and analysis. In many cases, workfare differs from earlier 'active' policies in response to unemployment in terms of normative discourse, rather than in terms of programme content, actual client obligation or performed activities. $^{2}$ Four major political frames for workfare in OECD countries can be identified on normative grounds: (I) social democratic; (2) labourist; (3) social conservative; and (4) neo-liberal.

In the social democratic discursive frame, workfare is very close to existing ALMPs, many of which are already obligatory to clients. This particularly concerns training policies that aim to develop the skills of unemployed workers in accordance with human capital approaches. The goal of such policies is to insert workers into mainstream employment. To this end, the policy instrument of choice is the provision of training for the unemployed. Such policies aim to avoid segmented labour markets and the development of low-wage sectors. They also avoid subsidization of low-wage labour through in-work benefits such as tax credits. Sweden, despite frequent bouts of self-doubt, remains the model country for such policies (Anxo and Niklasson 2004: I4I 6,36$)^{3}$

In the labourist discursive frame, formal inclusion in the labour market is highlighted, and the quality of employment is of secondary importance. Workfare is understood as the organization of transition between inactivity and any available job. The goal of workfare policies is to provide for social inclusion through a combination of paid employment plus in-work benefits for those whose market income remains below subsistence level. Such policies place the main emphasis on enforcing participation in the labour market, but they accept that the state must redistribute income through the tax system post hoc and must maintain some level of solidaristic redistribution among different sections of the labour force. Nevertheless, the labourist system accepts segmented labour markets, large skill dispersion and a high degree of wage inequality. Contemporary Britain has emerged as the ideal-type country representing the labourist workfare discourse (Salais 2004: 292).

The social conservative discursive frame conceives of workfare as part of the moral (counter-)reform of society. This interpretation of workfare stresses various ethical and societal values including self-reliance, behavioural control of clients and family formation. It also talks of a 'new paternalism' in social policy-making (Mead 1997). The goal is to link workfare programmes with norms and values, thereby applying workfare as a socio-cultural tool rather than as an end in itself. From an ideal-type perspective, one can locate the social conservative workfare discourse at the level of competition between and within political parties. One might identify sections of the Republican and Democratic Parties in the USA, as well as sections of conservative and 
Christian Democratic parties in Europe, as those who adhere to this approach.

Finally, the neo-liberal discursive frame conceptualizes workfare as part of a strategy to minimize states' regulatory role in the labour market. Here, workfare programmes have the limited objective of speeding up clients' reemployment. Although not hostile to education and training policies as such, advocates of neo-liberalism demand that these policies should be organized by private providers as markets rather than the state. They aim to run workfare policies as 'slim' operations without any broader concern for education and training issues. Their goal is rather limited in scope - to increase outflow from benefits by reorganizing the benefit system in a manner that increases benefit conditionality, cuts entitlements and reduces overall spending levels. Another key feature of the neo-liberal workfare approach is its eagerness to introduce market mechanisms into programme delivery itself. This can involve 'contracting out', partial or full privatization of employment services and paying the latter by results. All these features serve to turn programme delivery into an agency-changing strategy that challenges the legitimacy of any direct labour market intervention. In the ig8os, UK policies were typical of this approach (Ginsburg 200I).

In order to analyse workfare further, one must acknowledge the crucial importance of both discursive competition and discursive agreement between the four major normative positions on workfare. Each of the four positions grants legitimacy for workfare as a policy. Yet each position also favours rather different instrument settings for workfare. The four positions overlap in certain ways, but are opposed in others. For example, the labourist and neo-liberal positions might agree on work-first approaches, but they disagree on whether or not in-work benefits are necessary to correct market outcomes. On the other hand, both the social conservative and the labourist approaches stress concerns with societal values and a normative commitment to the 'right to work'. One must, therefore, acknowledge that workfare policies can be the result of compromise between different policy paradigms and that their existence depends on political coalition-building. In sum, the exact overlap between different policy paradigms on the issue of workfare is not fixed. Policy entrepreneurship connects policy-making paradigms with policy instruments and instrument settings, and thereby determines the workfare policies of the OECD countries.

\section{Workfare in its Broader Policy-making Context}

This section puts forward an ideal-type overview of all policy options that concern 'active' responses to unemployment in OECD countries. It does this by scrutinizing the differences between traditional ALMP and more recent workfare. In order to clarify these differences, one must first examine how ALMP (the concept) and ALMPs (the policies) have been defined in the academic debate before and after their rise to OECD-wide prominence in the ig6os.

The earliest comprehensive concept of ALMP emerged in Sweden in the I950s. ALMP formed one element of the country's full employment strategy 
- the 'Rehn-Meidner model', named after two prominent economists of the Swedish trade union federation LO. This model combined restrictive macroeconomic fiscal and monetary policies with economy-wide wage coordination to guarantee full employment. Within the framework of the model, ALMPs performed a labour-mobilizing role - speeding up workers' transition from traditional to modern sectors of employment (Blyth 2002: I2 I-3).

Swedish ALMPs were general in scope. They demanded that workers accept sectoral and/or regional mobility. However, the element of compulsion was balanced out by economy-wide solidaristic wage bargaining. A coordinated wage-setting process between trade unions and employers established a single national wage rate in each field of employment. Thus, it encouraged the increased provision of education and training policies for all sections of labour. National wage coordination supported investment in human capital to increase labour productivity across the economy as a whole. At the same time, employment in less productive firms and sectors of the economy declined as these were unable to pay wage increases that rose along with national productivity growth. The role of ALMPs, then, was to enable the unemployed to take up opportunities in the growth firms and sectors. It placed emphasis on the development of their human capital through training and subsequent movement from low- to high-productivity employment. In sum, despite the element of compulsion, 'first-wave' ALMP was different from contemporary workfare in so far as it made a direct connection between compulsion and solidaristic wage policies, human capital generation and productivity growth (Erixon I997; Meidner I998). Moreover, Swedish firstwave ALMP was very demanding in institutional terms. Consequently, the 'bundle' of Swedish policies had to be 'untied' in order to make the concept applicable in other OECD countries.

From the mid-I96os, the transition from first-wave ALMP to second-wave ALMP took place. Initially, institutions such as the OECD began to disseminate ALMP under the banner of 'active manpower policies'. After i973, when structural mass unemployment reappeared in many OECD countries, second-wave ALMP became more prominent. Crucially, ALMP ceased to be directly linked with macro-economic policy-making and became more limited in scope. It now involved the extension of public employment services, a limited commitment to education and training policies and, at least initially, some support for ad hoc public sector job creation. Thus, the strong human capital orientation of the first wave was downgraded in the second wave. By now, any kind of labour market training became defined as active policy. Only after this transition in the early i970s did second-wave ALMP emerge on an OECDwide scale. ALMP tried to do 'more with less': due to rising unemployment, the supply of potential clients for active schemes increased. However, at the same time, the earlier commitment to human capital development declined.

Thus, the 'separating-off' of ALMP from broader macro-economic policies left these policies without any overarching policy paradigm (Dostal 2004: $44^{\mathrm{I}-2}$. In this context, eclectic workfare-style policies began to enter the OECD debate in small steps from the mid-I97os, but they were only fully acknowledged in the iggos. Young people, in particular, were singled out for recruitment into obligatory programmes, and their right of access to passive 
benefits was made dependent on participation in active policies. From the mid-I970s, many 'quasi-workfarist' features, such as obligatory participation in schemes where the human capital-building orientation was notional rather than substantial, became part of the active response to unemployment. The difference between these and more recent workfare schemes was more to be found in the way they were described at the level of discourse rather than their content.

In order to analyse similarities and differences between earlier ALMP and recent workfare, a taxonomy of all potential policy responses to the condition of unemployment as well as other forms of 'inactivity' is required. Such a taxonomy can help to establish an analytical borderline between ALMP and workfare; it also clarifies the relative degree of influence of workfare approaches on political responses to unemployment in OECD countries.

Established active responses to unemployment can be divided into four 'ideal-types' that, taken together, cover all currently existing policy instruments in the field of work/welfare policies. These ideal-types concern (I) general ALMPs; (2) targeted ALMPs; (3) market workfare; (4) 'make-work' workfare. Each of these four policy-types shares the application of a certain similar instrument setting, namely the application of 'status-changing' policy tools that assist or compel benefit recipients to cooperate in attempts to move them into work, training or other activities. The most fundamental distinction between ALMPs and workfare at the level of policy instruments is that the former concentrate on human capital development through education and training policies. Workfare, on the other hand, is based on a work- or activity-first approach, which gives priority to rapid labour force attachment over all other policy goals (Peck 200I; Theodore and Peck 2000). Thus, ALMPs aim to improve the labour market prospects of the unemployed by improving their skills prior to, or simultaneously with, insertion into employment. Workfare aims to move clients into work and 'activities', without parallel attempts to raise their skill levels as part of programme design. In the words of one anonymous supervisor of US workfare implementation: 'You do not need to get an education to get a job; to get a job, you need to work' (quoted in Mead 200i: 529).

Another crucial analytical step is to acknowledge that ALMPs and workfare both entail two major subcategories. First, ALMPs can be directed towards a wide population, or they can be aimed at certain target groups. In the first case, general ALMPs serve the purpose of improving skill levels across all sectors of a national labour force. Such general ALMPs are part of a strategy to improve workers' skills and to link skill generation with labour market mobilization and mobility. They depend for their success on other labour market mechanisms such as solidaristic wage bargaining, coordination between employment sectors and a high degree of labour market homogeneity. They also require policy-makers to take effective steps to avoid segmented labour markets, and in particular low-wage sectors that are not linked with the overarching wage coordination system. It follows that general ALMPs have always remained rather exceptional in the OECD. Such policies were pursued in Sweden and some other Nordic countries, but could not be transferred to other OECD countries. 
By contrast, the second category of targeted ALMPs has been much more commonly used across the OECD world. Here, policies focus on specific target groups in the labour market such as young people, older workers, the long-term unemployed and other disadvantaged groups. They involve different degrees of commitment to clients, and they include education and training efforts as well as public work creation in the service of training objectives. At one end of the spectrum, such policies entail support for clients to participate in vocational training or higher education. They might offer substantial commitment to improve clients' long-term prospects in the labour market. At the other end of the spectrum, they involve short-term courses with a very low degree of human capital development, and they often have a rather symbolic content. Typically, the more generous targeted ALMPs are strongly biased towards young people and aim to reinsert them into mainstream education and training. On the other hand, short-term courses are often targeted at the long-term unemployed to 'interrupt' the unemployment spell through active measures - at least for statistical purposes. Follow-up studies of clients who have participated in long-term programmes with a substantive human capital content and in short-term programmes of the work-first type do not give consistent results. In some cases, programmes with the highest degree of human capital generation, such as long-term vocational training, perform much better than short-term programmes (Lechner et al. 2005: 43, 49). In other cases, short-term programmes are most successful in reinserting people into employment, particularly if evaluation adopts an agnostic view on the quality of the employment in question (Martin 2000). However, only some of these differences can be explained by internal features of targeted ALMPs. Most of them derive from differences in national employment systems. For example, countries with a developed vocational training system might produce better results through the use of long-term programmes rather than short-term programmes aimed at inserting workers into low-skilled employment. ${ }^{4}$

The third and fourth types of active policies cover workfare. Here, it is crucial to acknowledge that workfare consists of two rather different concepts, namely market workfare and make-work workfare. The former concept relates to the labour market and waged labour, while the latter relates to the administrative imposition of 'work' by the authorities responsible for paying benefits. In the case of market workfare, the focus is on moving benefitdependent groups, such as the long-term unemployed, lone parents and the sick and disabled, closer to the labour market. In particular, market workfare aims to make these groups more 'employable' through administrative means, especially through fiscal policies that subsidize low-wage employment. By doing so, it aims to control wage inflation by ensuring that an effective 'reserve army' of labour exists: all 'workless' groups, not just the officially unemployed, are turned into potential low-wage workers. It is to be noted that this particular form of workfare differs from its traditional and more narrow definition of forcing clients to work in return for their benefits, as is the case in make-work workfare (Grover and Stewart 1999, 2000; Grover 2003: I8; Koch et al. 2005: 20).

However, 'market workfare' (the term used by Grover and Stewart) is more difficult to analyse than most observers have so far acknowledged. 
While Grover is correct to argue that market workfare concerns policies that pursue a close relationship between the reserve army and the labour market, he fails to appreciate the actual policy mix which has been advanced by the Labour government since I997. As Peter Mandelson correctly stated in I998: '[the] welfare-to-work programme makes the labour market flexible . . . It increases the supply of labour in the economy, its quality and its employability' (quoted in Grover 2003: I9; emphasis added). What this suggests is that market workfare operates as part of a broader strategy that acknowledges the trade-off in policy between a pure low-wage strategy and a more complex strategy that tries to put pressure on wages while increasing effective skill supply. Moreover, market workfare tries to do this without prioritizing one goal at the cost of the other. In short, British market workfare includes a large number of interrelated policies, such as the national minimum wage, in-work benefits, national childcare strategy, as well as the various New Deal programmes for different categories of the unemployed (cf. the next section). More recently, it has also included attempts to question existing entitlements in other British benefit programmes such as Incapacity Benefit. This makes it appropriate to speak about a particular British style of market workfare, which consists of a combination of policy instruments not prevalent in other countries.

In the USA, on the other hand, market workfare was used in many federal states to provide private employers with direct access to the welfare population. In some cases, private companies became directly involved in the running of welfare-to-work programmes in order that they might fill entry-level positions in areas with high costs of living, where labour recruitment had become difficult. Thus, US-style market workfare was concerned with direct administrative measures to fill vacancies. By contrast, British market workfare entailed a larger number of policy instruments and, paradoxically, placed more trust in market outcomes. It relied on the notion that increased effective supply would generate increased employment in entry-level jobs, while avoiding any large-scale extension of make-work programmes. To summarize, versions of market workfare in Britain and the USA share some similarities, but they differ in terms of programme implementation. Both countries subsidize low-wage workers through tax credits, but the British programme is considerably more generous to single earners and part-time workers (Blundell 200I; Mead 2004). This is a crucial difference, as it serves to limit the weekly working hours of single earners in the UK. By contrast, many single earners in the USA work very long hours to achieve a subsistence-level income. In the UK, longer hours of employment simply trigger the withdrawal of in-work benefits.

Furthermore, market workfare differs at the level of policy implementation from targeted ALMPs. Whenever clients enter low-wage employment under market workfare they are subsidized by in-work benefits. However, there is no commitment to education or training. On the other hand, whenever such employment offers education and training, it can be classified as a version of targeted ALMPs. Thus, the decisive difference between ALMPs and market workfare is the formal commitment to education and training in programme implementation, although targeted ALMPs tend to overlap in practice with market workfare if the commitment to skill development is weak. 
Finally, make-work workfare is the policy instrument of last resort. It concerns clients who have failed to gain employment in the private or public sector and entails 'work for the dole'. Here, the benefit authorities create a 'work test' that consists of activities outside of the regular labour market to check clients' willingness to be available for work in order to keep their benefit entitlement. Yet make-work workfare faces a number of crucial shortcomings that limit its applicability and reach. Such policies must be 'additional' to avoid competition with existing private and public sector employment. Consequently, the work must take place under the control of some public authority. This suggests employment of a 'non-productive' or 'symbolic' character. Yet such policies then fail to give clients access to any marketable skills, and they might even stigmatize them further. Thus, for everyone concerned, make-work workfare is 'artificial' employment of doubtful utility. One might argue that the actual function of such policies is to act as a disciplinary device rather than an active response to unemployment. However, many clients with a long-term benefit history already hold very low expectations. Often, they do not perceive such work schemes as punitive and willingly accept the imposition of 'activity'. In this case, public authorities might face the rise of a large sector of unproductive labour under their direct administrative command, and they have to take direct responsibility for the weakest client groups in public work schemes of last resort. Thus, the work test might fail to motivate clients to search for waged employment, especially if clients' expected market wage is very low.

To sum up, the four major 'active' policy responses to unemployment often appear less distinctive than the current typology suggests. In fact, all policies are located on a sliding scale and crucially depend on certain shared instrument settings. They all aim to ease client transitions from benefit status to work, other activities, transfer between benefits, exclusion from the benefit system, or, indeed, from the status of 'officially recognized unemployment' to some 'undeserving status'. In fact, this burden-shifting function can feature in each of the four policies discussed above. Instrument settings all feature prominently, including direct wage subsidies, in-work benefits, temporary subsidies for self-employment, and administrative redefinitions of criteria for benefit entitlement that are intended to enforce status change away from unemployment. Often, criteria for 'officially recognized unemployment' status are made more discriminating, thereby excluding certain groups, such as young people or cohabiting partners with one partner in employment, from the unemployment count. At other times, benefit entitlements are simply cut. The political character of such status-changing tools depends entirely on their relationship to larger policy objectives that derive from the four policies already discussed (compare table I).

The division of OECD states' 'active' responses to unemployment into the four ideal-type responses allows all existing policy instruments - i.e., the individual components of any 'active' programme - to be linked with one of the analytical categories. ${ }^{5}$ Table I shows the analytical distinction between the two versions of ALMP as well as between the two versions of workfare. The overarching difference between both policy categories is the distinction between the human capital approach of ALMPs and the exclusive concern 
Table I

Four ideal-type responses to unemployment and 'inactivity' in OECD countries

\begin{tabular}{|c|c|c|c|c|}
\hline Policy instrument & General ALMPs & Targeted ALMPs & Market workfare & Make-work workfare \\
\hline Target population & All workers & $\begin{array}{l}\text { Target groups } \\
\text { such as young } \\
\text { and older } \\
\text { workers, } \\
\text { disadvantaged } \\
\text { groups }\end{array}$ & $\begin{array}{l}\text { All workers in the } \\
\text { low-wage sector }\end{array}$ & $\begin{array}{l}\text { Long-term } \\
\text { benefit clients }\end{array}$ \\
\hline Instrument settings & $\begin{array}{l}\text { Large-scale } \\
\text { education and } \\
\text { training policies } \\
\text { informed by } \\
\text { national } \\
\text { standard-setting } \\
\text { bodies }\end{array}$ & $\begin{array}{l}\text { Some education } \\
\text { and training } \\
\text { policies, } \\
\text { temporary wage } \\
\text { subsidies for } \\
\text { employers } \\
\text { or employees }\end{array}$ & $\begin{array}{l}\text { Permanent } \\
\text { in-work benefits } \\
\text { for employees } \\
\text { delivered through } \\
\text { the tax/benefit } \\
\text { system }\end{array}$ & $\begin{array}{l}\text { Additional work } \\
\text { creation outside } \\
\text { of the wage labour } \\
\text { system under state } \\
\text { supervision }\end{array}$ \\
\hline Policy goals & $\begin{array}{l}\text { General increase } \\
\text { of human capital of } \\
\text { average worker, } \\
\text { increase in labour } \\
\text { productivity }\end{array}$ & $\begin{array}{l}\text { Redistribution } \\
\text { of labour } \\
\text { market risk in } \\
\text { favour of workers } \\
\text { with below-average } \\
\text { human capital }\end{array}$ & $\begin{array}{l}\text { Maximization of } \\
\text { quantitative } \\
\text { employment } \\
\text { outcomes without } \\
\text { concern for labour } \\
\text { productivity }\end{array}$ & $\begin{array}{l}\text { Work test, screening of } \\
\text { the benefit population }\end{array}$ \\
\hline Application & $\begin{array}{l}\text { Sweden from the } \\
\text { I950s until the } \\
\text { early ig9os }\end{array}$ & $\begin{array}{l}\text { Most OECD } \\
\text { countries } \\
\text { since the I97os }\end{array}$ & $\begin{array}{l}\text { Many OECD } \\
\text { countries, most } \\
\text { common in liberal } \\
\text { welfare regimes } \\
\text { since the } \\
\text { Ig8os }\end{array}$ & $\begin{array}{l}\text { Many OECD countries, more } \\
\text { prominent since the I99os }\end{array}$ \\
\hline
\end{tabular}


for labour force attachment in workfare approaches. This distinction is crucial in the analysis of policy-making content of 'active' responses to unemployment at the national level.

For the purposes of policy analysis, OECD welfare regime types will continue to differ with regard to their particular policy mix between versions of ALMP and versions of workfare. Yet all OECD countries currently cover at least some features of the last three categories of policies outlined in table I - that is, targeted ALMP, market workfare and make-work workfare.

The next section turns to the UK case to demonstrate that post-I997 welfare reform has not challenged the underlying continuity of 'active' responses to unemployment. Rather, welfare reform has resulted in a reorganization of trade-offs between the three major policy instruments. Crucially, the fundamentally cyclical pattern of policy-making remains in place: the rise of tax-benefit policies to encourage the take-up of work and to increase the employment headcount continues to interact with and compete with policies that focus primarily on human capital development and attempts to increase the quality of employment.

\section{The Case of the United Kingdom between 1997 and 2007: Workfare Discourse without Workfare?}

Since I997, the British Labour government has been keen to claim in public that it has managed to find new ways of dealing with the problem of unemployment. In an oft-quoted phrase, its discourse has stressed that the welfare state should be transformed from a 'safety net of demands into a springboard of self-responsibility' (Blair and Schröder I999; my translation). The British response to unemployment has been the New Deal (ND) programme, which is also sometimes referred to as welfare reform. This programme, introduced in 1998 and initially funded by a windfall tax on the privatized utilities, has been exceptionally successful in capturing the imagination of academic social policy observers. It was also successful in communication exercises by the Labour government with the broader public and the mass media. Most early observers suggested that the ND amounted to 'workfare'. Participation in the programme was made obligatory for unemployed clients receiving the Jobseeker's Allowance (JSA), the major out-of-work benefit in Britain after a client had spent a certain period on 'passive' benefits. Some analysts also suggested that UK policy derived from transatlantic policy learning and was inspired by the US experience (Daguerre 2004).

However, this early interpretation has become less convincing on a number of counts. Its only remaining strong point is its stress on the similarities of the discourse on workfare between the USA and the UK. Yet as soon as one moves from discourse to practical policy-making, analysing the level of policy instruments, the claim of extensive 'policy learning' by the UK from the USA can no longer be maintained. First, the British benefit system is too complex and entrenched to offer a springboard for US-style abolition of passive programmes. Second, its administration of unemployment and 'inactivity' has always been highly dualistic as far as the structure of the benefit system is concerned. Its major historic feature has been its 
characteristic shift of 'difficult' groups among the unemployed from the 'claimant count' of clients receiving JSA to a secondary benefit, Incapacity Benefit (IB), ${ }^{6}$ which is granted on health grounds as a National Insurance benefit, or to Income Support (IS) as the means-tested benefit of last resort (Alcock 2006: I82-4). Only the JSA client group has been subject to 'actively seeking work' rules since I989, making the granting of benefit conditional on job search. By contrast, the IB and IS client groups have historically been excluded from 'active' policies. This dualistic feature of the British benefit system has resulted in regular migration of 'difficult' long-term clients away from the 'active' JSA regime to the 'passive' IB/IS regime. Such client transfer had a structural component, being a reaction to deteriorations in the labour market, but was sometimes also steered according to political convenience. Whenever 'opened', the transfer of clients from active to passive benefits brought down official British unemployment figures, which are defined as the JSA claimant count (Beatty and Fothergill 2003; Price 2000: 250-I). ${ }^{7}$

Most recently, this process has been slowed down and the number of IB recipients has been stabilized at the historically high level of around 2.7 million. It remains contested, however, whether this is due to government reforms or a general improvement in the labour market. Nevertheless, the dualistic features of the benefit system remain in place. Research on participants' destinations after participating in active programmes makes clear that many clients circulate back and forth between these programmes and passive benefits (Carpenter 2006: 2I-2).

Thus, the point of departure of recent welfare reform in the UK was the acceptance of the policy-making heritage of benefit dualism. In fact, resources for active responses to unemployment still continue to be concentrated on those sections of the unemployed judged to be closest to the labour market. The ND programme is first and foremost an attempt to communicate with the broader public and to maximize political credit-claiming. It aims to present a number of very different programmes for different target groups as belonging to a single 'delivery platform'. At first glance, all ND programmes appear to belong to a single coherent, active response to unemployment. Yet the various programmes - most significantly the ND for young people (NDYP), ND 25 plus (ND25) for the long-term unemployed aged 25 to $49,^{8}$ and ND for lone parents (NDLP) - were in fact different programmes involving different policy instruments for different target groups (National Statistics 2004; Jobcentre Plus 2005). The programme essentially continues the tradition of earlier ALMPs to 'target' resources on the most promising client groups, namely younger workers who are most likely to pay back investment in their human capital at a later point in time in subsequent benefit savings. By far the largest share of spending on ND programmes concerns NDYP and, to a lesser extent, ND25, while spending on other ND programmes for 'non-traditional' clients such as lone parents has been comparatively small. Moreover, due to declining UK unemployment since the mid-I9gos, the number of people participating in the ND programmes has been much lower than was the case for earlier active programmes in the late I970s and Ig8os.

The most significant feature of the ND has been the introduction of a new terminology to describe the long-standing institutional practices of the 
Jobcentre (the British Public Employment Service). This new terminology concerns the interaction between Jobcentre staff and their clients. Crucially, for the overwhelming majority of ND clients the programme amounts to a change in their interview regime at the Jobcentre, rather than any direct offer of active programmes. In fact, most clients enter neither ALMPs, nor market or make-work workfare (Dostal 2005: 279-93). Thus, the ND programme has been perceived as successful in the eyes of the public because its internal properties aim to avoid risk-taking at the implementation level. In the language of Hall (r993), the ND mainly concerns the adaptation of already existing 'instrument settings', i.e. the interview regime at Jobcentres, rather than a shift of emphasis from passive to active policies. In fact, the active elements of the programme are very limited in scope and reach. They largely concern those client groups that already enjoyed access to active policies in earlier programmes.

To show that this is, indeed, the correct way of interpreting the logic of the ND programmes since I998, the following analysis looks at the three main ND options (NDYP, ND25 and NDLP) and considers their internal properties in accordance with the division of policy instruments advanced in table I (cf. the previous section).

The most important programme, NDYP, deals with unemployed clients aged I 8 to 24 who enter the programme after an uninterrupted six-month spell on JSA in the so-called 'gateway'. The gateway is a time span of six months during which client advisers conduct fortnightly interviews to find as many employment opportunities as possible for their clients. Even very short placements in employment interrupt the spell in JSA for the purposes of the programme and count as a successful outcome. For two-thirds of young people, the gateway is the ND experience and only a minority of participants enter the second stage - the so-called 'options'. The options, in turn, aim to improve the employability of young people who cannot obtain unsubsidized jobs in the private sector (Finn 2003). They consist of vocational education of up to 52 weeks; subsidized short-term employment in the private sector; and work in the voluntary sector or in an environmental task force. First, the educational option belongs to traditional targeted ALMP due to its human capital orientation. Second, in the subsidized employment option, the contribution to clients' human capital is so limited in scope that one can qualify the option as located on the borderline between targeted ALMP and market workfare. Finally, the work option in the voluntary sector and the environmental task force is a 'last resort' solution and amounts to make-work workfare (compare table I). Crucially, the workfare features of the non-educational options are made less severe due to the circulation of clients back to passive JSA after participation in the active ND options. Thus, clients who fail to enter employment continue to circulate between options and the regular benefit system. Once their option is over, they re-enter the interview routine in the Jobcentre and either regain their previous JSA benefit status or move on to other benefits, as is frequently the case.

The second major programme, $\mathrm{ND}_{25}$, for long-term unemployed clients aged between 25 and 49, targets clients who previously received JSA for 24 months (since 200I, the period has been I8 months). This programme 
demands that clients enter an 'advisory process' of between three and six months, which consists of an increased number of interviews conducted by Jobcentre staff. This process was subsequently renamed 'gateway' in order to increase presentational similarities with the NDYP. However, the ND25 does not offer the same degree of access to 'options' such as subsidized employment or full-time education. Such instruments were only available to a small number of ND25 clients, while the majority simply moved back towards JSA status once the advisory process was finished. In 200I, the programme was changed in line with the NDYP and a new device of the intensive activity period' (IAP) was added to the gateway. This IAP period lasts for I 3 weeks (in exceptional cases up to 26 weeks) and includes options such as work experience; work placement with employers; occupational training; help with motivation and soft skills; and a 'basic employability training' (Coleman et al. 2004: 5-7). What all these options have in common is that they are cheaper to provide, are of shorter duration and have minimal or no human capital focus in programme content in comparison with the more generous NDYP options.

The third programme, NDLP, is even more limited in scope. In can be accessed by lone parents receiving Income Support, which is the British benefit of last resort for single parents who are normally not expected to work until their children reach the age of I4. Since April 200 I all lone parents have been obliged to participate in mandatory 'work-focused interviews' (WFI) once their youngest child reaches the age of five years and three months. These interviews take place on an annual basis and do not require lone parents to accept any subsequent work obligation. From October 2004, the interviews have included a so-called 'mandatory action plan'. This change is interesting to observe on account of its misleading terminology, as it places mandatory obligations on benefit advisers rather than on clients. That is, it becomes 'compulsory for advisers to complete an action plan during all lone parent work focused interviews . . . [T] hese plans do not have to be agreed by the lone parent or include any further action or "next step" which need to be completed by the lone parent before the next WFI' (Thomas and Jones 2006: 25; emphasis added). The rather symbolic nature of this policy is due to the fact that 'active' resources continue to be in limited supply. In fact, they mostly remain targeted at the classical clients of earlier ALMPs, namely young people and some sections of the long-term unemployed. Thomas and Jones also note a perceived general lack of training opportunities available to lone parents (2006: I6), thereby confirming that nearly a decade of welfare reform in Britain has not delivered any substantial extension of education and training policies to 'non-traditional' clients.

In sum, the Labour government's active policies in response to unemployment, such as the various ND programmes, have tried to project the impression of a 'tightening-up' of the benefit regime to the broader public. However, actual policy change has been limited in scope and has mostly focused on the renaming of existing policy instruments such as the interview regime between Jobcentre staff and their clients. Thus, access to active employment measures is still limited. Such measures mostly concern short spells in work or basic skill training, as was already well known from earlier British ALMPs in the 
I970s and I980s. Furthermore, they also follow the classical hierarchy of target group policy-making in earlier ALMPs, with a primary focus on young people, a secondary focus on the long-term unemployed, but with much lower spending per client in comparison with the first group, and a tertiary focus evident only in some symbolic spending on all other groups.

Therefore, to the extent that there is any increase in the rate of 'activation' of clients at all in comparison with earlier periods, it is due to the tight limit on spending for expensive human capital measures such as education and training. In fact, the large majority of active measures refer only to work experience without substantial training content and fairly short periods of client activation. Furthermore, the direct imposition of workfare-type policies is narrowly limited in scope and includes a time limit on participation in 'make-work' schemes, after which clients are allowed to re-enter the passive benefit regime. This concerns essentially the NDYP and some of its 'options', as previously discussed. Overall, the policing of the system in terms of benefit sanctions has remained similar to that operating in the pre-Labour and preNew Deal period. Most benefit sanctions are short-term and result from the failure of clients to make themselves available for interviews rather than any more specific policing in a workfare manner. ${ }^{9}$ The entire ND programme amounts to a rather successful attempt to maximize political credit-claiming within existing resource constraints. In fact, the ND changes the paradigmatic discourse of earlier ALMPs without any parallel shift in actual policy implementation. The programme speaks in the language of workfare to the broader public, but mostly avoids such policies in the actual interaction with clients.

This underlying continuity has also remained in place in the latest effort to reform the Incapacity Benefit. The government Green Paper (26 January 2006) focused on new efforts to move people from IB back towards mainstream active programmes whenever feasible. This effort was based on the planned renaming of IB as 'Employment and Support Allowance' from 2008. This new measure would involve a new client capability assessment that distinguishes between 'eligibility for the benefit and capability for work' (DWP 2006a: 12, 39). In order to improve targeted support for IB clients, the government suggests the extension of the currently voluntary 'Pathway to Work' programmes of adult training. However, these attempts to change existing boundaries between clients, agencies and benefit assessments have run into strong criticism from disability rights groups, whose representatives question policies that are based on obligatory 'work-related activities' and instead demand individual targeted support on a voluntary basis (DWP 2006b: i6).

Looking at the larger picture, one can again detect the underlying cyclical pattern of trade-offs in 'active' policy-making. In the period since 1997, most efforts had been conducted under the banner of 'welfare to work', thereby extending active provisions to more and more client groups - with the most difficult IB reform attempt as the final stage of the cycle. These efforts have been based on curtailment of spending per client for education and training efforts with an increase in spending on tax credits (the British version of inwork benefits). 
Yet most recently, policy initiatives point once again towards increased emphasis on 'classical' education and training efforts. The British government has been keen to expand certified training provisions for young workers and for already employed workers without qualifications. This has resulted in changed funding priorities, moving resources away from existing adult education courses to a more narrow focus on level 2 National Vocational Qualifications (Kingston 2006). However, these moves have come at a high cost - they include shifts in agency control from the Jobcentre to the Learning and Skills Council and a destabilization of existing adult educational provisions. Any future reform effort will continue to face the problem that clients who are furthest away from the labour market might be less attractive to support in an active manner than those who are close to the mainstream labour market. Neither welfare reform nor the renaming of agencies and benefits will change this underlying pattern of continuity, and it will necessarily result in the periodical shift of funding back towards core constituencies.

\section{Conclusion}

Ever since their rise to OECD-wide prominence in the I97os, 'active' responses to unemployment have suffered from policy-makers' unrealistic expectations about their potential abilities to exercise direct causal influence on employment levels. Yet the success or failure of ALMP is essentially determined more by macro-economic policies than by the inherent design features of the measures themselves. In spite of the decline of Keynesian doctrines in the steering of the economic cycle, the relative success of ALMPs remains dependent on macro-economic performance. Shifts in the internal properties of active policies are always of secondary importance. Furthermore, the fundamental properties of active policy instruments remain similar over time, although the credit-claiming discourse might change. Such policies concern supply-side issues in the labour market as well as the policing of the passive benefit system. Policy-making continually circulates between efforts to increase human capital generation through education and training schemes and efforts to force the unemployed to take substandard jobs in the hope that their prospects might improve over time once they are employed. In addition, the policing of the passive benefit system periodically gives rise to the introduction of 'work tests' that are organized by public authorities to check clients' willingness to accept the direct imposition of work to protect their benefit entitlement.

In spite of underlying policy-making continuity, policy-makers can always resort to the one single element of active responses to unemployment that can be changed at very low cost: discourse. There is no doubt that policymakers' legitimizing discourses and credit-claiming efforts have changed considerably since the iggos. The rise of workfare as the object of creditclaiming has certainly been a new feature. However, one should not confuse workfare discourse, as a symptom of neo-liberal restructuring within OECD capitalism, with the actual substance of neo-liberal policy change. In fact, the policy-making instrument of workfare is not significant enough to exercise any major causal influence on its own. The main object of neo-liberal 
restructuring efforts remains people who are in or close to the labour market, rather than those sections of society whose labour market attachment is weak. Thus, the shift in discourse away from earlier solidaristic interpretations of ALMP to the current concern to accept market outcomes, or to limit policy-making to some remedial action through in-work benefits, is one outcome of neo-liberal restructuring, but it is not where the major emphasis is placed. Rather, the most recent discourse could be seen as the reappearance of classical liberal doctrine to subordinate state intervention to the aim of making the labour market supposedly more efficient.

Turning towards the level of policy instruments, three major policy instruments are currently available to OECD policy-makers: (I) targeted ALMPs; (2) market workfare; and (3) make-work workfare. In the case of ALMP, the former Swedish version of general ALMP as an element of 'Keynesianism in one country' has run its course. What remains possible are more limited education and training efforts in targeted ALMPs. As for workfare, the drawing of a clear analytical distinction between its two manifestations, namely market workfare and make-work workfare, amounts to a major analytical step forward. However, one must once again stress that promoting market workfare, based on in-work benefits for low-wage workers, as analysed by Grover and others, does not represent a fundamental change of policy. Rather, such policies aim to improve the trade-off between 'free' wage labour and the direct administrative imposition of work. Under market workfare - but not under make-work workfare - the private employer remains in charge of enforcing discipline in the workplace. Thus, the system of subsidizing low-wage labour through in-work benefits does not point towards fundamental policy change, but rather to incremental adaptation of the existing tax/benefit system. In fact, the granting of tax privileges to groups with a low degree of labour market attachment and the ignoring of casual and low-hour employment for the purposes of taxation existed long before the rise of in-work benefits.

Hence, the large-scale introduction of in-work benefits in liberal welfare regimes is simply an acknowledgement of the fact that workers are unable to offer their labour power for wages below subsistence rates. Moreover, these benefits are financed through increased taxation of median earners and, in practice, replace certain formerly available passive benefits. Thus, in-work benefits constitute 'solidarity within one class', even if mediated through the fiscal state rather than through union-driven solidaristic wage bargaining. Such benefits also encourage employers to change their managerial strategies in favour of increasing the employment headcount, rather than to increase workers' average productivity through education and training. The major reason for the introduction of in-work benefits is that this policy takes advantage of the disciplinary power of private employers - which would be absent in the case of direct imposition of work. In sum, market workfare influences existing instrument settings of the tax/benefit system but does not transcend their limitations.

This leads to another major point: any kind of active response to unemployment - regardless of its political inspiration in social democratic, labourist, social conservative or neo-liberal normative frameworks - exercises a 
rather limited influence on employers' choices. All active policies, including those that aim for solidaristic redistribution of labour market risk, use rather weak tools to influence employers. Most evaluations of active responses to unemployment conclude that efforts to improve the position of marginal workers through employment subsidies or education and training efforts will be ignored by employers, as long as the level of unemployment is sufficient to ensure an adequate supply of qualified workers. Under such conditions, employers will choose to employ workers with recent labour market attachment, rather than workers with a long-term unemployment record, even if the latter worker would be subsidized by public funds. This demonstrates another paradox of active policies: their actual impact on labour market outcomes will be weakest when demand for them should be highest, that is, during periods of a cyclical increase in unemployment.

In conclusion, the actual potential of the 'activation' of labour market policy and of welfare reform in the OECD remains limited to two major policy choices. First, the relative balance between each of the three available policies - namely, targeted ALMP, market workfare and make-work workfare - can be changed and each policy can be expanded at the cost of one of the others. Second, 'general' instrument settings of policy-making, such as funding level and method of delivery, can also be changed. However, these changes do not differ fundamentally from other changes in policy that concern resource allocation. They certainly do not point to any fundamental regime change within OECD capitalism. Moreover, the paradigms, instruments and specific instrument settings also remain similar in their logic over time. Here, shifts in the normative discourse cannot be backed up by any fundamental policy-making change at the implementation level.

There is little reason to believe that policy-makers can solve these problems by shifting towards more authoritarian, active policies. In fact, once OECD states remove labour market protection of 'insiders', they encounter increased militancy of 'insider' workers faced with prospects of redundancy. After all, active policies often perform the function of 'side payment' in order to limit the costs that workers incur in the case of job loss. Once such protective features are removed, they result in the decline of corporatist patterns of policy-making and threaten alliances between social democratic parties and trade unions in those OECD societies in which they had achieved hegemony in the past. It is, therefore, important to stress that US-style welfare reform cannot be compared with reforms made in other OECD societies. The profile of the AFDC client population in the USA was very different from the profile of the unemployed in countries such as Britain and Germany. Moreover, the type of macro-economic stimulation that has occurred in the USA since the mid-Ig9os has not occurred in other OECD countries and the prospects for employment growth are therefore rather different.

What OECD societies need is a more honest debate between supranational, national and local actors about the kind of active policy response to unemployment they are willing to support. Deliberation should be concerned with all policy instruments and instrument settings, and the terms of policymaking success and failure should be made clear. Crucially, success and failure cannot be decided upon through some quantitative measurement of 
employment outcomes (Ashiagbor 2005: 178-85). After all, the outcome of active programmes will always remain overdetermined by macro-economic factors that these policies cannot influence. Over time, such an open debate on norms and values could result in a new societal contract that would determine how the burden of unemployment should be distributed. Furthermore, such deliberation could also show that neo-liberal hegemony is not a necessary feature of the current period, and even that its existence is, in part, a consequence of the absence of debate. The 'groundhog day' ${ }^{10}$ experience of neo-liberal welfare reform certainly is not the only available option.

\section{Acknowledgements}

I am grateful to Andreas Bieler, Bernard Casey, Larissa Douglass, Deborah Mabbett and two anonymous referees for helpful comments.

\section{Notes}

I. In the film Groundhog Day, actor Bill Murray plays a weatherman who reluctantly covers a story about a groundhog whose behaviour during an annual village festival is believed to forecast the end of winter. The day after covering the 'event', Murray notices that this day is exactly the same as the day before. He already knows everything that is going to happen and is doomed to spend the rest of eternity in the same place, observing the same people doing the same thing every day.

2. For example, the post-I998 German employment scheme for young people 'Immediate Programme for Youth' (German abbreviation JUMP) targeted young people aged below 25 and threatened to withdraw their benefits in order to make them participate in active measures. The threat of benefit withdrawal also underpinned the German 'Hartz Reforms' after 2003. In the former case, no reference to workfare was made, while post-2003 it was increasingly referred to.

3. The crucial element of change in recent Swedish ALMPs since 2002 has been the abolition of the right of clients to re-qualify for wage replacement payments after participation in ALMPs (the 'carousel effect'). This change challenges clients' status protection and increases clients' risk of experiencing downward mobility in the event of them becoming unemployed.

4. There is a tendency in British evaluation of active policies to suggest that measures that subsidize employment in the mainstream labour market result in larger outflow from unemployment than policies that aim to improve clients' human capital through education and training. Furthermore, this outflow is sometimes sustained (Coleman et al. 2004: I9). However, it is difficult to judge whether this points to inherent superiority of rapid employment in the workplace or, as is likely, to the tendency of benefit advisers to select the 'strongest' candidates for subsidized employment while moving 'weaker' candidates to other options, including skill training. Another major issue in programme evaluation concerns the duration of analysis. Many work-first programmes redistribute employment, while many education and skill programmes redistribute employment trajectories. The latter type of programme can exercise a long-term influence on employment status and quality that is captured only in a long-term evaluation of clients' subsequent labour market status.

5. There are, of course, innovations in the field of active responses to unemployment that belong to none of the four categories. For example, the establishment of the British Jobcentre Plus network, and the associated use of 'personal advisers' 
and 'work-focused interviews', does not constitute the introduction of separate policy instruments. Instead, it changes the institutional framework for programme delivery. However, such institutional change only influences trade-offs between competing objectives. For example, evaluation of the Jobcentre Plus the new agency that brings the former Benefits Agency (the Social Security offices) and the Employment Service together - has suggested that small improvements in job brokering were paid for by parallel substantial decline in the accuracy of benefit delivery (Karagiannaki 2007: I I-I4).

6. This benefit was known as Invalidity Benefit until i995. The I995 reform, renaming the benefit, was made in order to limit inflow of new clients through more rigid screening of clients' capability to work.

7. IB performed the functional equivalent of early retirement policies in other OECD countries, in so far as it dealt with structural change and the decline of traditional industrial jobs.

8. In the early literature, the $\mathrm{ND}_{25}$ plus programme was also referred to as the New Deal for Long-Term Unemployed People (NDLTU). Since then, the term has been abandoned because of its self-defeating connotation.

9. Wilkinson reports that 'only 2.6 per cent of $\mathrm{ND}_{25}$ plus participants had ever been sanctioned, with the majority of these receiving only a two week sanction. Less than o.I per cent of all ND 25 plus participants have been sanctioned on more than two occasions' (2003: 2I). The most recent evaluation of the three major active benefit regimes JSA, NDYP and ND 25 plus suggests that 96 per cent of all clients are never sanctioned, while of the remaining 4 per cent of clients 73 per cent are sanctioned once, I6 per cent twice and io per cent more than twice (Peters and Joyce 2006: 2, 39).

Io. See note I.

\section{References}

Alcock, P. (2006), Understanding Poverty (3rd edn), Basingstoke: Palgrave.

Anxo, D. and Niklasson, H. (2004), The Swedish Model in Turbulent Times: Decline or Renaissance? Centre for Labour Market Policy Research, Växjö University. Available at: http://iat-info.iatge.de (accessed 2i November 2006).

Ashiagbor, D. (2005), The European Employment Strategy: Labour Market Regulation and New Governance, Oxford: Oxford University Press.

Barbier, J.-C. (2005), Activating Social Protection and Employment Insurance, tlm.net Working Paper, Amsterdam: SISWO/Social Policy Research.

Barbier, J.-C. and Ludwig-Mayerhofer, W. (2004), Introduction: the many worlds of activation, European Societies, 6, 4: 423-36.

Beatty, C. and Fothergill, S. (2003), Incapacity benefit and unemployment. In P. Alcock, C. Beatty, S. Fothergill, R. Macmillan and S. Yeandle (eds), Work to Welfare: How Men Become Detached from the Labour Market, Cambridge: Cambridge University Press, pp. II I-39.

Blair, T. and Schröder, G. (1999), Der Weg nach vorne für Europas Sozialdemokraten, Ein Vorschlag von Gerhard Schröder und Tony Blair, London (8 June). Available at: http://www.glasnost.de (accessed 2i November 2006).

Blundell, R. (200I), Welfare reform for low income workers, Oxford Economic Papers, 53: I89-2I4.

Blyth, M. (2002), Great Transformations: Economic Ideas and Institutional Change in the Twentieth Century, Cambridge: Cambridge University Press.

Carpenter, H. (2006), Repeat Jobseeker's Allowance Spells, Department for Work and Pensions Research Report no. 394, London: DWP.

Casey, B. H. and Gold, M. (2005), Peer review of labour market programmes in the 
European Union: what can countries really learn from one another? fournal of European Public Policy, I2, I: 23-43.

Coleman, N., Wapshott, J. and Carpenter, H. (2004), Destination of Leavers from NDTP and ND25 Plus, 3rd Draft Report (September), BMRB Social Research.

Daguerre, A. (2004), Importing workfare: policy transfer of social and labour market policies from the USA to Britain under New Labour, Social Policy E Administration, 38, I: $4^{\mathrm{I}-} 5^{6}$.

Digby, A. (I989), British Welfare Policy: Workhouse to Workfare, London: Faber and Faber.

Dolowitz, D. P., Hulme, R., Nellis, M. and O’Neal, F. (2000), Policy Transfer and British Social Policy: Learning from the USA? Maidenhead: Open University Press.

Dostal, J. M. (2004), Campaigning on expertise: how the OECD framed EU welfare and labour market policies - and why success could trigger failure, fournal of European Public Policy, II, 3: 440-6o.

Dostal, J. M. (2005), The political administration of unemployment: explaining the British and German case 1973-2003. DPhil dissertation, University of Oxford.

DWP (Department for Work and Pensions) (2006a), A New Deal for Welfare: Empowering People to Work, Green Paper (24 January), London: DWP.

DWP (2006b), A New Deal for Welfare: Empowering People to Work, Consultation report (i9 June), London: DWP.

Erixon, L. (I997), The father of the Swedish model: in memory of Gösta Rehn (I9I396), Economic and Industrial Democracy, i8, 4: 635-50.

Finn, D. (2003), The 'employment-first' welfare state: lessons from the New Deal for Young People, Social Policy \& Administration, 37, 7: 709-24.

Ginsburg, N. (200I), Globalization and the liberal welfare state. In R. Sykes, B. Palier and P. M. Prior (eds), Globalization and European Welfare States: Challenges and Change, Basingstoke: Palgrave, pp. I73-91.

Gottschalk, P. (1998), The impact of changes in public employment on low-wage labour markets. In R. Freeman and P. Gottschalk (eds), Generating Fobs: How to Increase Demand for Less-skilled Workers, New York: Russell Sage Foundation, pp. 72-IoI.

Grover, C. (2003), 'New Labour', welfare reform and the reserve army of labour, Capital and Class, 79: 17-23.

Grover, C. and Stewart, J. (I999), 'Market workfare': social security, social regulation and competitiveness in the ig9os, Fournal of Social Policy, 28, I: 73-96.

Grover, C. and Stewart, J. (2000), Modernizing social security? Labour and its welfare-to-work strategy, Social Policy $\mathcal{E}$ Administration, 34, 3: $235^{-52 .}$

Hall, P. A. (I993), Policy paradigms, social learning, and the state: the case of economic policymaking in Britain, Comparative Politics, 25, 3: 275-96.

Handler, J. (2003), Social citizenship and workfare in the US and Western Europe: from status to contract, Fournal of European Social Policy, I3, 3: 229-43.

Jessop, B. (2002), The Future of the Capitalist State, Cambridge: Polity Press.

Jobcentre Plus (2005), Additional Information on New Deal for Young People (NDYP). Available at: http://www.jobcentreplus.gov.uk (accessed 2I November 2006).

Karagiannaki, E. (2007), Exploring the effects of integrated benefit systems and active labour market policies: evidence from Jobcentre Plus in the UK. Paper given at the 5th ISSA Research Conference on Social Security, Warsaw, 5-7 March.

Kildal, N. (2000), Workfare tendencies in Scandinavian welfare policies. Paper given at the 8th BIEN Congress: Economic Citizenship Rights for the 2Ist Century, Berlin, 6-7 October.

Kingston, P. (2006), Tug of war for cash to train jobseekers, Guardian (I8 April).

Koch, S., Stephan, G. and Walwei, U. (2005), Workfare: Möglichkeiten und Grenzen, IAB Discussion Paper i7, Nuremberg: Bundesagentur für Arbeit. 
Lechner, M., Miquel, R. and Wunsch, C. (2005), Long-run Effects of Public Sector Sponsored Training in West Germany, IAB Discussion Paper I3, Nuremberg: Bundesagentur für Arbeit.

Lee, D., Marsden, D., Rickman, P. and Duncombe, J. (I990), Scheming for Youth: A Study of MTS in the Enterprise Culture, Milton Keynes: Open University Press.

Lipman, H. (1977), 'Workfare' and welfare, The Nation, 225, 5 (20 August): I4I-4.

Lødemel, I. and Trickey, H. (200I), An Offer You Can't Refuse: Workfare in International Perspective, Bristol: Polity Press.

Martin, J. P. (2000), What works among active labour market policies: evidence from OECD countries' experience, OECD Economic Studies, 30: 79-113.

Mead, L. M. (1997), The New Paternalism: Supervisory Approaches to Poverty, Washington, DC: Brookings Institution Press.

Mead, L. M. (200I), Welfare reform in Wisconsin: the local role, Administration and Society, 33, 5: 523-54.

Mead, L. M. (2004), Government Matters: Welfare Reform in Wisconsin, Princeton, NJ: Princeton University Press.

Meidner, R. (1998), The rise and fall of the Swedish model: interview with Rudolf Meidner, introduced by B. Silverman, Challenge, 4I, r: 69-9o.

Mohr, K. (2004), Pfadabhängige Restrukturierung oder Konvergenz? Reformen in der Arbeitslosenversicherung und der Sozialhilfe in Großbritannien und Deutschland, Zeitschrift für Sozialreform, 50, 3: 283-312.

National Statistics (2004), New Deal for Young People and Long-term Unemployed People Aged 25+: Background Information. Available at: http://www.dwp.gov.uk (accessed 2I November 2006).

Peck, J. (200I), Workfare States, New York: Guilford Press.

Peck, J. and Theodore, N. (2000), 'Work first': workfare and the regulation of contingent labour markets, Cambridge fournal of Economics, 24, I: II9-38.

Peters, B. G. (2005), I'm OK, you're (not) OK: the private welfare state in the United States, Social Policy \& Administration, 39, 2: г66-80.

Peters, M. and Joyce, L. (2006), A Review of the JSA Sanctions Regime: Summary Research Findings, Department for Work and Pensions Research Report no. 313, London: DWP.

Price, D. (2000), Office of Hope: A History of the Employment Service, London: Policy Studies Institute.

Rose, N. E. (200I), Public employment programs, workfare, and welfare reform, Review of Radical Political Economics, 33, 3: 28I-6.

Salais, R. (2004), Incorporating the capability approach into social and employment policies. In R. Salais and R. Villeneuve (eds), Europe and the Politics of Capabilities, Cambridge: Cambridge University Press, pp. 283-300.

Theodore, N. and Peck, J. (2000), Searching for best practice in welfare-to-work: the means, the method and the message, Policy and Politics, 29, r: 81-98.

Thomas, A. and Jones, G. (2006), Work Focused Interviews and Lone Parent Initiatives: Further Analysis of Policies and Pilots, Department for Work and Pensions Research Report no. 319, London: DWP.

White, S. (2004), What's wrong with workfare? Journal of Applied Philosophy, 21: 27I-84.

Wilkinson, F. (200I), The theory and practice of wage subsidisation: some historical reflections. Available at: http://www.radstats.org.uk (accessed 2i November 2006).

Wilkinson, D. (2003), New Deal for People Aged 25 and Over: A Synthesis Report, PSI Research Discussion Paper 15, London: Policy Studies Institute. 